Article

\title{
Correlation between the Potency of Flavonoids on Mushroom Tyrosinase Inhibitory Activity and Melanin Synthesis in Melanocytes
}

\author{
Worrawat Promden ${ }^{1, *}(\mathbb{D})$, Wittawat Viriyabancha ${ }^{2}$, Orawan Monthakantirat ${ }^{3}$, Kaoru Umehara ${ }^{4,5}$, \\ Hiroshi Noguchi ${ }^{4,6}$ and Wanchai De-Eknamkul ${ }^{7, *}$ \\ 1 Division of General Science, Faculty of Education, Buriram Rajabhat University, Buriram 31000, Thailand \\ 2 Bureau of Drug Control, Food and Drug Administration, Ministry of Public Health, \\ Nonthaburi 11000, Thailand; wittawat.vi@gmail.com \\ 3 Division of Pharmaceutical Chemistry, Faculty of Pharmaceutical Sciences, \\ Khon Kaen University, Khon Kaen 40002, Thailand; oramon@kku.ac.th \\ 4 School of Pharmaceutical Sciences, University of Shizuoka, Shizuoka 422-8526, Japan; \\ kaoru.umehara@hamayaku.ac.jp (K.U.); h-noguchi@nichiyaku.ac.jp (H.N.) \\ 5 Faculty of Pharmaceutical Sciences, Yokohama University of Pharmacy, Yokohama, \\ Kanagawa 245-0066, Japan \\ 6 Department of Pharmacognosy, Nihon Pharmaceutical University, Kitaadachi, Saitama 362-0806, Japan \\ 7 Natural Product Biotechnology Research Unit, Department of Pharmacognosy, Faculty of Pharmaceutical \\ Sciences, Chulalongkorn University, Bangkok 10330, Thailand \\ * Correspondences: worrawat.pd@bru.ac.th (W.P.); Wanchai.D@Chula.ac.th (W.D.-E.); \\ Tel.: +66-89-424-2324 (W.P.); +66-2-218-8393 (W.D.-E.)
}

Received: 6 May 2018; Accepted: 8 June 2018; Published: 9 June 2018

\begin{abstract}
Twenty-seven flavonoids isolated from Dalbergia parviflora with vast structural diversity were screened for inhibitory activity against mushroom and murine tyrosinases using L-DOPA as the substrate. Among the flavonoids tested, only four-khrinone (5), cajanin (9), (3RS)-3'-hydroxy-8-methoxy vestitol (21), and (6aR,11aR)-3,8-dihydroxy-9-methoxy pterocarpan (27) - reacted with mushroom tyrosinase, with $\mathrm{IC}_{50}$ values of $54.0,67.9,67.8$, and $16.7 \mu \mathrm{M}$, respectively, and only compound 27 showed inhibitory activity against murine tyrosinase. With cell-based assays, only compounds 9 and 27 effectively inhibited melanogenesis in B16-F10 melanoma cells (by 34\% and $59 \%$, respectively), at a concentration of $15 \mu \mathrm{M}$, without being significantly toxic to the cells. However, the crude extract of D. parviflora and some of the flavonoid constituents appeared to increase melanin production in B16-F10 cells, suggesting that there are flavonoids with both inhibitory and stimulatory melanogenesis in the crude extract. Studies on the correlation between the enzyme-based and cell-based assays showed that only the flavonoids with $\mathrm{IC}_{50}$ values below $50 \mu \mathrm{M}$ against mushroom tyrosinase could inhibit the mammalian tyrosinase, and thus, reduce melanogenesis in B16-F10. Flavonoids with the $\mathrm{IC}_{50}$ values greater than $50 \mu \mathrm{M}$, on the other hand, could not inhibit the mammalian tyrosinase, and had either no effect or enhancement of melanogenesis. In conclusion, the tyrosinase enzyme from mushroom is not as selective as the one from mammalian source for the enzyme-based melanogenesis inhibitory screening, and the mammalian cell-based assay appears to be a more reliable model for screening than the enzyme-based one.
\end{abstract}

Keywords: tyrosinase; flavonoid; Dalbergia parviflora; melanogenesis

\section{Introduction}

Tyrosinase (EC 1.14.18.1) is the key enzyme involved in melanin biosynthesis in living organisms. In animal cells, tyrosinase oxidizes L-tyrosine to 3,4-dihydroxyphenylalanine (L-DOPA), 
and subsequently, L-DOPA to DOPA quinone, in the initial steps in melanogenesis, a process which is mainly responsible for dark skin color. In plant-derived foods, tyrosinase catalyzes the oxidation of phenolic compounds to their corresponding quinones, and is responsible for the enzymatic browning of fruits and vegetables [1]. Therefore, tyrosinase inhibitors have become increasingly important in the cosmetic field as skin-whitening agents and in the food industry [2-5].

Mushroom tyrosinase has been widely used as a substitute for mammalian tyrosinase to screen for tyrosinase inhibitors as it is inexpensive and commercially available in a purified form [5]. Several plant flavonoids have been reported to have varying degrees of inhibitory activity towards mushroom tyrosinase, and are thought to be potential inhibitors of melanin synthesis in mammalian melanocytes [6-8]. However, there is a limitation of information about the correlation between the inhibitory activity of mushroom tyrosinase by flavonoids and the actual inhibitory effect of melanin formation in mammalian cells. Only one report has indicated that the inhibition rate of mushroom tyrosinase might not accurately reflect the inhibition rate of melanin synthesis in melanocytes [9]. We have reported, previously, the isolation and structure of estrogenic-like compounds from the heartwood of Dalbergia parviflora, a Thai folk medicine traditionally used as a blood tonic and menstruation normalizer. More than 60 flavonoids were isolated and identified, including 22 isoflavones, 12 isoflavanones, 10 isoflavans, six flavonones, four flavanonols, and six pterocarpans $[10,11]$. The structure-antioxidant relationship in the isoflavonoids from D. parviflora has also been reported [12]. The structural diversity of the flavonoids has provided a good source for studying the correlation between enzymatic assay and cell-based assays.

In this study, crude extract and 27 flavonoids prepared and isolated from the heartwood of $D$. parviflora were tested for their ability to inhibit mushroom and murine tyrosinases using L-DOPA as the substrate. The inhibition of mushroom tyrosinase was then compared to the inhibition of crude murine tyrosinase extracted from B16-F10 melanoma cells. Finally, the effects of these compounds on the overall melanin production in B16-F10 melanoma cells were studied to observe the correlation between the results of the enzyme-based and cell-based assays.

\section{Results and Discussion}

\subsection{Inhibitory Effect of Flavonoids on the o-Diphenolase Activity of Mushroom Tyrosinase}

The structures of the 27 flavonoids isolated from D. parviflora, grouped into isoflavones, flavanones, isoflavanones, isoflavans, and pterocarpan, are shown in Table 1. Each compound $(200 \mu \mathrm{M})$ was screened for $o$-diphenolase inhibitory activity of mushroom tyrosinase using L-DOPA as the substrate. A total of 11 active inhibitors from the preliminary screening were then determined for their $50 \%$ of inhibition $\left(\mathrm{IC}_{50}\right)$ values, and the results are summarized in Table 2.

Table 1. Chemical structures of tested compounds from the heartwood of Dalbergia parviflora.

\begin{tabular}{|c|c|c|c|c|c|c|c|c|c|}
\hline & No. & Isoflavones & R5 & R6 & R7 & $\mathbf{R} 2^{\prime}$ & $\mathbf{R} 3^{\prime}$ & $\mathbf{R} 4^{\prime}$ & $\mathbf{R} 5^{\prime}$ \\
\hline & 2 & Calycosin & $\mathrm{H}$ & $\mathrm{H}$ & $\mathrm{OH}$ & $\mathrm{H}$ & $\mathrm{OH}$ & $\mathrm{OMe}$ & $\mathrm{H}$ \\
\hline & 4 & Genistein & $\mathrm{OH}$ & $\mathrm{H}$ & $\mathrm{OH}$ & $\mathrm{H}$ & $\mathrm{H}$ & $\mathrm{OH}$ & $\mathrm{H}$ \\
\hline R5 & 5 & Khrinone B & $\mathrm{OH}$ & $\mathrm{H}$ & $\mathrm{OH}$ & $\mathrm{OH}$ & $\mathrm{H}$ & $\mathrm{OMe}$ & $\mathrm{OH}$ \\
\hline & 6 & 3'-O-Methylorobol & $\mathrm{OH}$ & $\mathrm{H}$ & $\mathrm{OH}$ & $\mathrm{H}$ & $\mathrm{OMe}$ & $\mathrm{OH}$ & $\mathrm{H}$ \\
\hline & 9 & Cajanin & $\mathrm{OH}$ & $\mathrm{H}$ & $\mathrm{OMe}$ & $\mathrm{OH}$ & $\mathrm{H}$ & $\mathrm{OH}$ & $\mathrm{H}$ \\
\hline
\end{tabular}


Table 1. Cont

\begin{tabular}{|c|c|c|c|c|c|c|c|c|c|}
\hline & No. & Isoflavanones & R5 & R6 & R7 & $\mathbf{R} 2^{\prime}$ & $\mathbf{R} 3^{\prime}$ & $\mathbf{R} \mathbf{4}^{\prime}$ & $\mathbf{R}^{\prime}$ \\
\hline & 10 & $\begin{array}{l}(3 R)-7,3^{\prime} \text {-Dihydroxy- } 4^{\prime}- \\
\text { methoxy-isoflavanone }\end{array}$ & $\mathrm{H}$ & $\mathrm{H}$ & $\mathrm{OH}$ & $\mathrm{H}$ & $\mathrm{OH}$ & $\mathrm{OMe}$ & $\mathrm{H}$ \\
\hline & 11 & Onogenin & $\mathrm{H}$ & $\mathrm{H}$ & $\mathrm{OH}$ & $\mathrm{OMe}$ & $\mathrm{H}$ & \multicolumn{2}{|c|}{$\mathrm{OCH}_{2} \mathrm{O}$} \\
\hline & 12 & Dalparvin & $\mathrm{H}$ & $\mathrm{H}$ & $\mathrm{OH}$ & $\mathrm{OMe}$ & $\mathrm{H}$ & $\mathrm{OMe}$ & $\mathrm{OH}$ \\
\hline & 13 & Dalparvin B & $\mathrm{H}$ & $\mathrm{H}$ & $\mathrm{OH}$ & $\mathrm{OH}$ & $\mathrm{OMe}$ & $\mathrm{OMe}$ & $\mathrm{H}$ \\
\hline & 14 & (3S)-Sativanone & $\mathrm{H}$ & $\mathrm{H}$ & $\mathrm{OH}$ & $\mathrm{OMe}$ & $\mathrm{H}$ & $\mathrm{OMe}$ & $\mathrm{H}$ \\
\hline & 15 & $(3 R, S)-3^{\prime}-O-$-Methylviolanone & $\mathrm{H}$ & $\mathrm{H}$ & $\mathrm{OH}$ & $\mathrm{OMe}$ & $\mathrm{OMe}$ & $\mathrm{OMe}$ & $\mathrm{H}$ \\
\hline \multirow{3}{*}{ Isoflavanones } & 16 & $(3 R, S)$-Kenusanone $G$ & $\mathrm{OH}$ & $\mathrm{H}$ & $\mathrm{OH}$ & $\mathrm{H}$ & $\mathrm{OH}$ & $\mathrm{OMe}$ & $\mathrm{H}$ \\
\hline & 17 & (3S)-Secundiflorol H & $\mathrm{OH}$ & $\mathrm{H}$ & $\mathrm{OH}$ & $\mathrm{OMe}$ & $\mathrm{OH}$ & $\mathrm{OMe}$ & $\mathrm{H}$ \\
\hline & 18 & Dalparvin A & $\mathrm{OH}$ & $\mathrm{H}$ & $\mathrm{OH}$ & $\mathrm{OMe}$ & $\mathrm{H}$ & $\mathrm{OMe}$ & $\mathrm{OH}$ \\
\hline \multirow[b]{6}{*}{ Isoflavans } & No. & Isoflavans & R6 & R7 & $\mathbf{R} 8$ & $\mathbf{R 2}^{\prime}$ & $\mathbf{R} 3^{\prime}$ & $\mathbf{R} 4^{\prime}$ & $\mathbf{R} \mathbf{5}^{\prime}$ \\
\hline & 19 & \multirow{3}{*}{$\begin{array}{l}\text { (3R)-Vestitol } \\
(3 R)(+) \text {-Mucronulatol } \\
(3 R, S)-3^{\prime} \text {-Hydroxy-8-methoxy } \\
\text { vestitol }\end{array}$} & $\mathrm{H}$ & $\mathrm{OH}$ & $\mathrm{H}$ & $\mathrm{OH}$ & $\mathrm{H}$ & $\mathrm{OMe}$ & $\mathrm{H}$ \\
\hline & 20 & & $\mathrm{H}$ & $\mathrm{OH}$ & $\mathrm{H}$ & $\mathrm{OMe}$ & $\mathrm{OH}$ & $\mathrm{OMe}$ & $\mathrm{H}$ \\
\hline & 21 & & $\mathrm{H}$ & $\mathrm{OH}$ & $\mathrm{OMe}$ & $\mathrm{OH}$ & $\mathrm{OH}$ & $\mathrm{OMe}$ & $\mathrm{H}$ \\
\hline & 22 & Duartin & $\mathrm{H}$ & $\mathrm{OH}$ & $\mathrm{OMe}$ & $\mathrm{OMe}$ & $\mathrm{OH}$ & $\mathrm{OMe}$ & $\mathrm{H}$ \\
\hline & 23 & (3S)-8-Demethylduartin & $\mathrm{H}$ & $\mathrm{OH}$ & $\mathrm{OH}$ & $\mathrm{OMe}$ & $\mathrm{OH}$ & $\mathrm{OMe}$ & $\mathrm{H}$ \\
\hline \multirow[b]{4}{*}{ Flavanones } & No. & Flavanones & R3 & R5 & R6 & R7 & $\mathbf{R} 4^{\prime}$ & $\mathrm{R} 5^{\prime}$ & $\mathbf{R} \mathbf{6}^{\prime}$ \\
\hline & 24 & (2S)-Liquiritigenin & $\mathrm{H}$ & $\mathrm{H}$ & $\mathrm{H}$ & $\mathrm{OH}$ & $\mathrm{OH}$ & $\mathrm{H}$ & $\mathrm{H}$ \\
\hline & 25 & (2S)-Naringenin & $\mathrm{H}$ & $\mathrm{OH}$ & $\mathrm{H}$ & $\mathrm{OH}$ & $\mathrm{OH}$ & $\mathrm{H}$ & $\mathrm{H}$ \\
\hline & 26 & Alpinetin & $\mathrm{H}$ & $\mathrm{OMe}$ & $\mathrm{H}$ & $\mathrm{OH}$ & $\mathrm{H}$ & $\mathrm{H}$ & $\mathrm{H}$ \\
\hline \multirow{3}{*}{ Pterocarpan } & No. & Pterocarpan & R5 & R6 & R7 & $\mathbf{R} 2^{\prime}$ & $\mathrm{R}^{\prime}$ & $\mathbf{R} 4^{\prime}$ & $\mathrm{R5}^{\prime}$ \\
\hline & 27 & $\begin{array}{l}(6 \mathrm{a} R, 11 \mathrm{a} R)-3,8 \text {-Dihydroxy- } \\
\text { 9-methoxy pterocarpan }\end{array}$ & $\mathrm{H}$ & $\mathrm{H}$ & $\mathrm{OH}$ & $\mathrm{H}$ & $\mathrm{OH}$ & \multirow[t]{2}{*}{$\mathrm{OMe}$} & \multirow[t]{2}{*}{$\mathrm{H}$} \\
\hline & & & & & & & & & \\
\hline
\end{tabular}

From the nine isoflavones (compounds 1-9), only two compounds with a hydroxyl group at the C-2' position of ring B-khrinone B (5) and cajanin (9)—exhibited $o$-diphenolase inhibitory potential, with $\mathrm{IC}_{50}$ values of $54.0 \pm 6.0$ and $67.9 \pm 6.2 \mu \mathrm{M}$, respectively. The other five isoflavones-namely formononetin (1), calycosin (2), biochanin A (3) 3'-O-methylorobol (6), and khrinone C (7)—did not show inhibitory activity on mushroom tyrosinase. In contrast to a previous report, calycosin has been shown to be a monophenolase inhibitor of mushroom tyrosinase with an $\mathrm{IC}_{50}$ value of $38.4 \mu \mathrm{M}$. In addition, calycosin reduced melanin biosynthesis in murine melan-a melanocytes [13]. Most of the isoflavanones, isoflavans, and flavanones showed poor or no inhibitory activity on tyrosinase. (3R,S)-3'-hydroxy-8-methyoxy vestitol (21), an isoflavan with hydroxyl groups at the R2' and R3' positions of ring $\mathrm{B}$, showed inhibition with an $\mathrm{IC}_{50}$ value of $67.8 \pm 5.8 \mu \mathrm{M}$. Pterocarpan (27) was the best mushroom tyrosinase inhibitor among the 27 flavonoids tested, with an $\mathrm{IC}_{50}$ value equal to kojic acid $(16.7 \pm 5.0 \mu \mathrm{M}$ and $16.8 \pm 4.8 \mu \mathrm{M}$, respectively). Moreover, the positive control, oxyresveratol, exhibited the strongest inhibitory effect on mushroom tyrosinase with an $\mathrm{IC}_{50}$ of $0.19 \pm 0.06 \mu \mathrm{M}$. The crude extract of $D$. parviflora exhibited tyrosinase inhibitory activity with an $\mathrm{IC}_{50}$ of $2.6 \pm 0.4 \mu \mathrm{g} / \mathrm{mL}$.

The inhibition of enzymes by certain flavonoids may be due to the interaction of the flavonoids with free radicals generated at the active sites of the enzymes [14] or with copper ion in the catalytic domains of the enzymes [7]. The numbers and positions of the hydroxyl groups attached to the flavonoids skeletons are the key to the inhibitory activity of mushroom tyrosinase. Chang et al. found that 6,7,4'-trihydroxyisoflavone, glycitein (6-methoxy-7,4'-dihydroxyisoflavone), daidzein (7, $4^{\prime}$-dihydroxyisoflavone), and genistein (5,7,4'-trihydroxyisoflavone) inhibited the monophenolase 
activity of mushroom tyrosinase with $\mathrm{IC}_{50}$ values of $9.2,237,264$, and $822 \mu \mathrm{M}$, respectively. The results suggest that the hydroxyl groups at the C6 and C7 positions of ring A of the isoflavone skeleton might play an important role in the expression of monophenolase inhibitory activity [15]. Chang et al. also found that 7,8, $4^{\prime}$-trihydroxyisoflavone and 5,7,8, $4^{\prime}$-tetrahydroxyisoflavone irreversibly inhibit the monophenolase and diphenolase activities of tyrosinase. The study suggested that the presence of hydroxyl groups at the C7 and C8 positions of the isoflavone skeleton may also cause this irreversible inhibition [16].

Table 2. Mushroom tyrosinase inhibitory activities of flavonoids extracted from Dalbergia parviflora.

\begin{tabular}{|c|c|c|c|}
\hline \multirow{2}{*}{ No. } & \multirow{2}{*}{ Compound } & \multicolumn{2}{|c|}{ Mushroom Tyrosinase Inhibition } \\
\hline & & $\%$ Inhibition (at $200 \mu \mathrm{M}$ ) & $I C_{50}(\mu \mathrm{M})$ \\
\hline (control) & Oxyresveratrol & $98.4 \pm 1.1$ & $0.19 \pm 0.1$ \\
\hline (control) & Kojic acid & $93.4 \pm 1.7$ & $16.8 \pm 4.6$ \\
\hline 27 & $(6 \mathrm{a} R, 11 \mathrm{a} R)-3,8$-Dihydroxy-9-methoxy pterocarpan & $84.6 \pm 0.6$ & $16.7 \pm 5.0$ \\
\hline 5 & Khrinone B & $72.7 \pm 2.2$ & $54.0 \pm 6.0$ \\
\hline 21 & (3RS)-3'-Hydroxy-8-methoxy vestitol & $64.1 \pm 1.3$ & $67.8 \pm 5.8$ \\
\hline 9 & Cajanin & $65.0 \pm 1.6$ & $67.9 \pm 6.2$ \\
\hline 10 & (3R)-7,3'-Dihydroxy-4'-methoxy-isoflavanone & $52.1 \pm 0.4$ & $176.7 \pm 16.3$ \\
\hline 24 & (2S)-Liquiritigenin & $52.1 \pm 1.4$ & $178.1 \pm 14.0$ \\
\hline 20 & $(3 R)(+)$-Mucronulatol & $48.3 \pm 1.6$ & $228.9 \pm 22.2$ \\
\hline 17 & (3S)-Secundiflorol H & $44.0 \pm 3.7$ & $278.1 \pm 54.5$ \\
\hline 26 & Alpinetin & $36.9 \pm 0.5$ & $450.0 \pm 48.5$ \\
\hline 19 & $(3 R)$-Vestitol & $35.6 \pm 2.2$ & $473.0 \pm 60.9$ \\
\hline 12 & Dalparvin & $31.6 \pm 0.5$ & $906.1 \pm 43.6$ \\
\hline 6 & 3'-O-Methylorobol & $14.3 \pm 1.1$ & N.D. \\
\hline 3 & Biochanin A & $9.2 \pm 0.4$ & N.D. \\
\hline 1 & Formononetin & $10 \%($ at $300 \mu \mathrm{M})$ & N.D. \\
\hline 7 & Khrinone C & $2 \%($ at $300 \mu \mathrm{M})$ & N.D. \\
\hline 2 & Calycosin & $0 \%($ at $300 \mu \mathrm{M})$ & N.D. \\
\hline 11 & Onogenin & $0 \%($ at $300 \mu \mathrm{M})$ & N.D. \\
\hline 15 & $(3 R, S)-3^{\prime}-O-$-Methylviolanone & $0 \%($ at $300 \mu \mathrm{M})$ & N.D. \\
\hline 13 & Dalparvin B & $4 \%($ at $500 \mu \mathrm{M})$ & N.D. \\
\hline 14 & (3S)-Sativanone & $13 \%($ at $500 \mu \mathrm{M})$ & N.D. \\
\hline 16 & $(3 R, S)$-Kenusanone G & $0 \%($ at $500 \mu \mathrm{M})$ & N.D. \\
\hline 18 & Dalparvin A & $0 \%($ at $500 \mu \mathrm{M})$ & N.D. \\
\hline 22 & Duartin & $0 \%($ at $500 \mu \mathrm{M})$ & N.D. \\
\hline 4 & Genistein & $\mathrm{S}^{*}$ & N.D. \\
\hline 8 & Tectorigenin & $\mathrm{S}^{*}$ & N.D. \\
\hline 23 & (3S)-8-Demethylduartin & $\mathrm{S}^{*}$ & N.D. \\
\hline 25 & (2S)-Naringenin & $\mathrm{S}^{*}$ & N.D. \\
\hline
\end{tabular}

N.D.: not determined; $S^{*}$ : These flavonoids can react with mushroom tyrosinase to form a colored product that interferes with the spectrophotometric measurement.

In the series of flavonoids in this study, only (3S)-8-demethylduartin (23) contained 7,8-dihydroxy groups. However, the inhibitory activities of khrinone B (5) and cajanin (9) suggested that not only the 6,7- or 7,8-dihydroxy groups of ring A, but also the hydroxyl group at the $\mathrm{C} 2$ ' position of ring $\mathrm{B}$ of isoflavone or isoflavanone skeletons, might play important roles in the expression of $o$-diphenolase inhibitory activity. The inhibitory activities of (3RS)-3'-hydroxy-8-methoxy vestitol (21) and $(6 \mathrm{a} R, 11 \mathrm{a} R)$-3,8-dihydroxy-9-methoxy pterocarpan (27) supported the importance of both the hydroxyl group at the $\mathrm{C}^{\prime}$ position on ring $\mathrm{B}$ of isoflavans and pterocarpan for $o$-diphenolase inhibitory activity.

In this study, the 7,8-dihydroxy groups are only present in (3S)-8-demethylduartin (23), which could be a potent tyrosinase inhibitor. However, after pre-incubation of (3S)-8-demethylduartin (23) with the enzyme in the absence of the substrate (L-DOPA), an orange metabolite with an optical density at $475 \mathrm{~nm}$ was observed. This observation suggests that (3S)-8-demethylduartin (23) can act as a chromogenic substrate analog for mushroom tyrosinase. The other flavonoids that were found to be chromogenic substrate analogs include genistein (4), tectorigenin (8), and (2S)-naringenin (25). These results are comparable to a previous report in which resveratrol, a phenylpropanoid, 
was oxidized by mushroom tyrosinase and converted to a newly oxidized compound which was observed at $475 \mathrm{~nm}$ and became a tyrosinase inhibitor [17,18]. Moreover, Gasowska-Bajger and Wojtasek demonstrated that the oxidation of quercetin, kaempferol, morin, catechin, and naringenin by mushroom tyrosinase strongly influenced the measurement of the absorbance at $475 \mathrm{~nm}$ during oxidation of L-tyrosine or L-DOPA, generating false inhibition or activation effects [19].

\subsection{Inhibitory Effect of Flavonoids on the o-Diphenolase Activity of Murine Tyrosinase}

The inhibition of murine tyrosinase was studied using the flavonoids at a concentration of $200 \mu \mathrm{M}$. The results revealed that among the 27 flavonoids, only $(6 \mathrm{a} R, 11 \mathrm{a} R)-3,8$-dihydroxy-9-methoxy pterocarpan (27) showed a weak inhibitory effect on the $o$-diphenolase activity of murine tyrosinase with an inhibition of $29.2 \pm 2.9 \%$ (Table 3 ). The crude extract and the other flavonoids did not show any inhibition (data not shown), whereas $200 \mu \mathrm{M}$ of kojic acid and oxyresveratrol, the positive controls, showed strong inhibitory effects of $73.8 \pm 1.0 \%\left(\mathrm{IC}_{50}=39.9 \mu \mathrm{M}\right)$ and $99.4 \pm 0.9 \%$ $\left(\mathrm{IC}_{50}=0.88 \pm 0.16 \mu \mathrm{M}\right)$, respectively.

Table 3. Murine tyrosinase inhibitory activity and melanogenesis of flavonoids from Dalbergia parviflora.

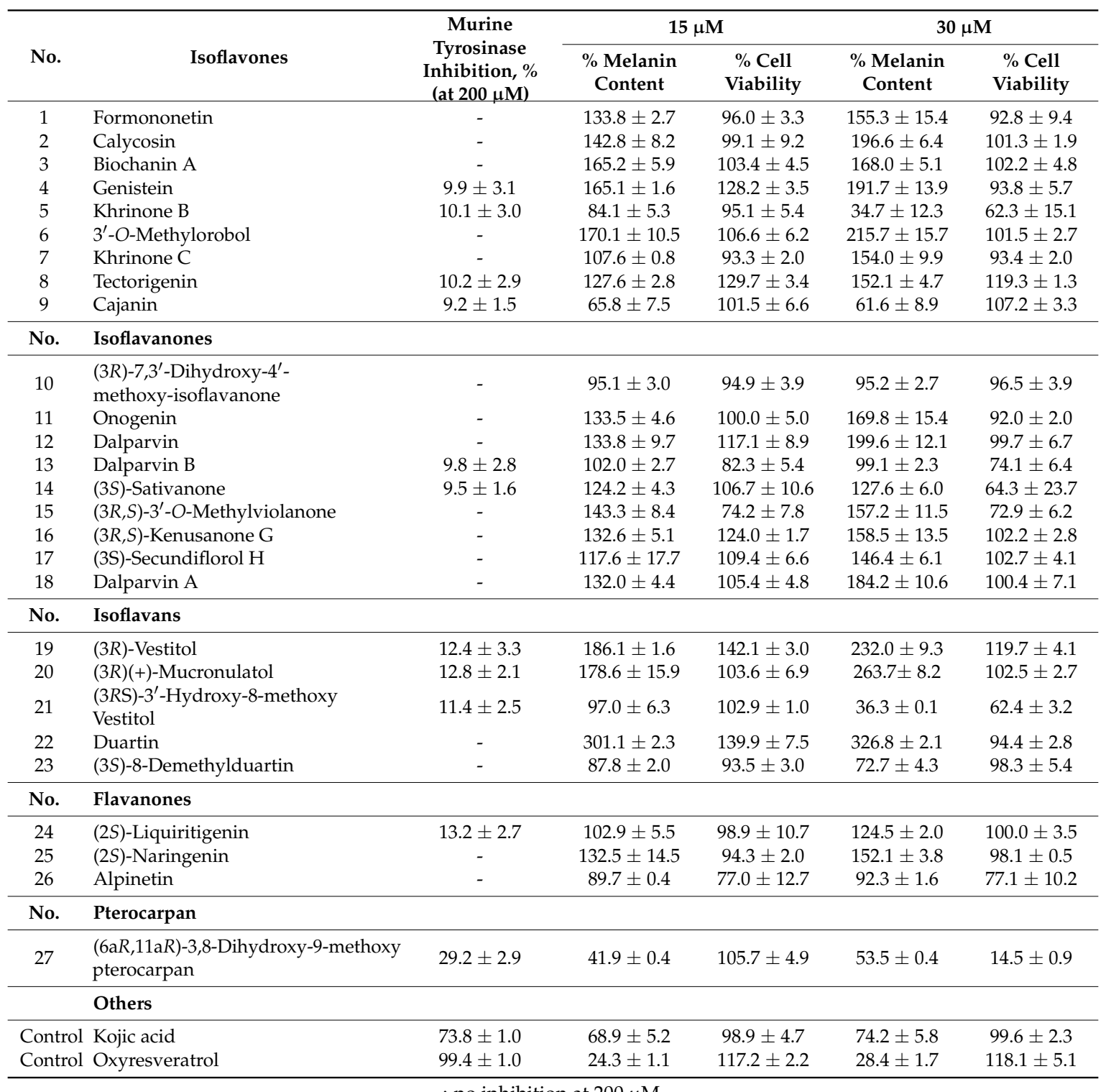


Notably, the flavonoids exhibited stronger effects on mushroom tyrosinase than murine tyrosinase activity. In fact, almost all studies conducted on tyrosinase inhibition have used the commercially available champignon mushroom (Agaricus bisporus) tyrosinase. Although these results may highlight that mushroom tyrosinase can be used for anti-tyrosinase activity screening, it does not appear to be sufficiently accurate to measure the potential of the active substance as a whitening agent. A more appropriate method would be to use the mammalian tyrosinase inhibition assay and melanogenesis inhibition results from the cell-based assay. However, mushroom tyrosinase is still a suitable screening tool to measure the anti-browning activity of plant-derived foods in the food industry.

\subsection{Effects of the Flavonoids on Cell Viability and Melanogenesis of B16-F10 Melanoma Cells}

Murine B16-F10 melanoma cells were used as a model to examine the effects of the 27 flavonoids on cell viability and melanogenesis (Table 2). The melanin content was measured at $405 \mathrm{~nm}$, a wavelength at which both pheomelanin and eumelanin absorb light [20]. The reason for using phenol red-free supplemented DMEM was that as cells grow, they produce lactic acid during cellular metabolism, which causes the $\mathrm{pH}$ of the medium to decrease. This decrease changes the phenol red DMEM medium to yellow, which interferes with the measurement of the brown melanin production recorded at $405 \mathrm{~nm}$. The results of the dark-brown cell culture are shown in Figure 1, which led to the measurement of cell viability and total melanin content (Table 3).

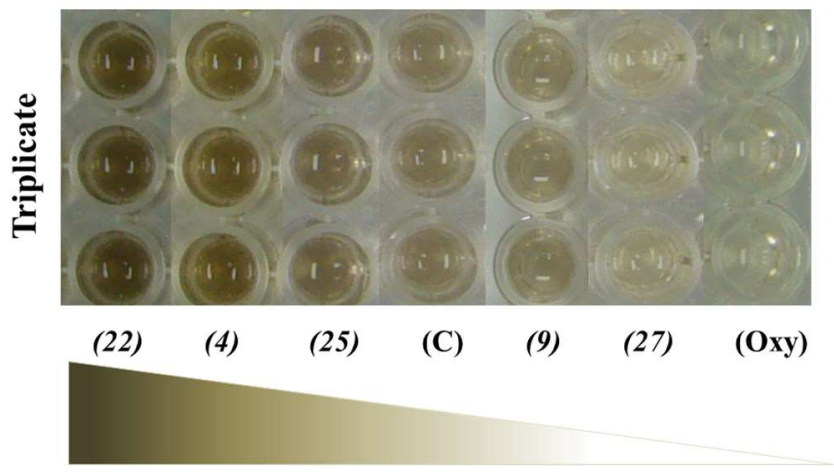

Figure 1. Total melanin content assay-the tested compound was added to a final concentration of $30 \mu \mathrm{M}$ of B16-F10 melanoma grown cells. The compounds genistein (4), duartin (22), and (2S)-naringenin (25) increased the melanin content. The inhibitory effect of melanogenesis was found in cajanin (9) and $(6 a R, 11 a R)-3,8$-dihydroxy-9-methoxy pterocarpan (27). Oxyresveratrol (Oxy) was used as a positive control. (C) is the negative control to which $0.5 \%$ dimethyl sulfoxide (DMSO) was added.

Compounds 13, 15, and 26 exhibited cytotoxicity against melanoma cells at a concentration of $15 \mu \mathrm{M}$ with the cell viability decreasing to approximately $70-80 \%$ of the control. Compounds $5, \mathbf{1 4}$, and 21 showed toxicity at a concentration of $30 \mu \mathrm{M}$ with a cell viability of $60 \%$. The highest cytotoxicity was found in compound 27, with a cell viability of $14 \%$ at $30 \mu \mathrm{M}$, but no toxicity was exhibited at $15 \mu \mathrm{M}$. Compounds 8, 16, 19, and 22 increased the quantity of melanoma cells with a cell viability of 120-140\% compared with the control at a concentration of $15 \mu \mathrm{M}$. The inhibitory effect of melanogenesis was found in compounds 9 and 27. Although compound 27 exhibited 60\% inhibition of melanogenesis at $15 \mu \mathrm{M}$ without affecting the cell viability, it showed cytotoxicity at $30 \mu \mathrm{M}$ (Table 3). Only compound 9 significantly decreased the cellular melanin content without affecting the cells at both concentrations.

From the 27 flavonoids tested, most of them increased melanin production, especially Duartin (22), which exhibited a three-fold increase in melanin content with respect to the control (Figure 1 and Table 3). Treatment of B16-F10 cells with the $D$. parviflora crude extract significantly promoted melanin formation in a dose-dependent manner. At the concentrations of $1.25,2.5,5.0$, and $10.0 \mu \mathrm{g} / \mathrm{mL}$ of the crude extract, the melanin content increased by $158,173,226$, and $288 \%$, respectively, without 
exhibiting toxicity (Figure 2). However, at the concentrations of 20, 30, and $40 \mu \mathrm{g} / \mathrm{mL}$, the cell viability decreased to 85,80 , and $75 \%$, respectively.

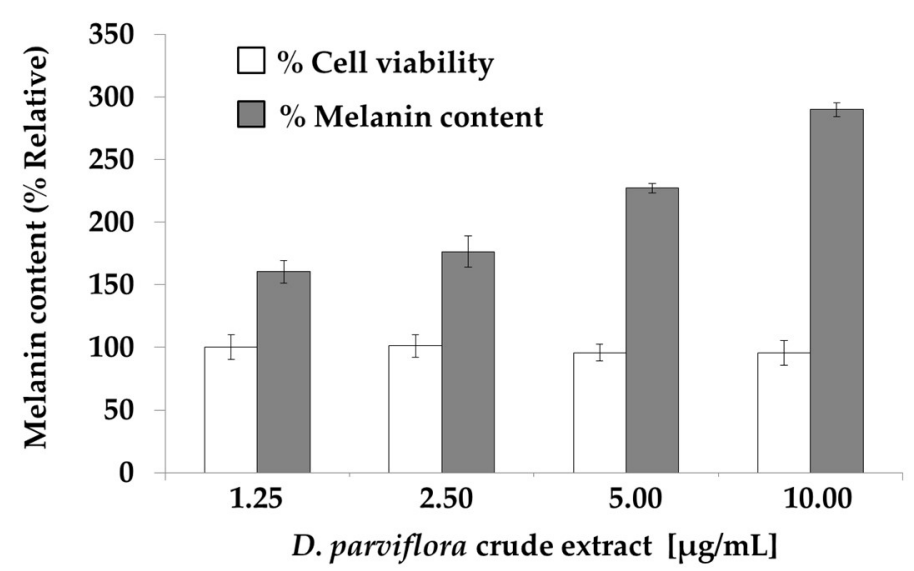

Figure 2. D. parviflora crude extract induced melanogenesis in B16-F10 melanoma cells. The cells were treated with the crude extract for $72 \mathrm{~h}$. Data represent means \pm SDs. The melanin content was significantly different between the control and treatment groups $(p<0.05)$.

A previous report indicated that quercetin and naringenin stimulate melanogenesis in cultured murine B16-F10 melanoma cells. Kubo et al. suggested that the improvement of melanin production by quercetin may be due, in part, to melanocytotoxicity [21], whereas Nagata et al. suggested that quercetin stimulates melanogenesis by increasing tyrosinase activity and decreasing other factors, such as melanogenic inhibitors [22]. Ohguchi et al. [23] and Bouzaiene et al. [24] also reported that naringenin increases the expression level of melanogenic enzymes in B16-F10. Takekoshi et al. reported that flavonoids, including quercetin, kaempferol, rhamnetin, fisetin, apigenin, luteolin, chrysin, and genestein, showed melanogenesis-promoting actions on human melanoma cells (MMV II), which promoted melanogenesis by flavonoids that was dependent on increased intracellular tyrosinase activity. Moreover, the relationship between the structure and melanogenesis-promoting actions of the flavonoids suggested that the hydroxyl group bound to the phenyl group plays an important role in the stimulation of melanogenesis [25]. In this study, the comparison of the chemical structures between duartin (22) and (3S)-8-demethylduartin (23) revealed that the 7,8-dihydroxy structure in the isoflavans was associated with melanogenesis inhibition. The R8-OMe substitution in duartin (22) had a strong effect on melanogenesis stimulation. The comparison of chemical structures between (3RS)-3'-hydroxy-8-methoxy vestitol (21) and duartin (22) also revealed that the $2^{\prime}, 3^{\prime}$-dihydroxy structure was associated with an inhibition of mushroom tyrosinase. Duartin (22), associated with $2^{\prime}$-methoxy structure, exhibited the strongest melanogenesis stimulation and loss of mushroom tyrosinase inhibitory activity.

All tyrosinases have a binuclear type three copper center within their active site in common. However, no common tyrosinase protein structure has been found to occur across all species [26-29]. There are significant differences between mushroom tyrosinase and mammalian tyrosinase in terms of structural properties, molecular properties, kinetic properties, and localization. Tyrosinase from the mushroom $A$. bisporus has been reported to be a soluble cytosolic enzyme containing two different subunits, referred to as heavy $(\mathrm{H})$ and light $(\mathrm{L})$, with molecular weights of 43 and $13.4 \mathrm{kDa}$, respectively. In aqueous solution, the predominant form of the mushroom tyrosinase is the quaternary $\mathrm{L}_{2} \mathrm{H}_{2}$ structure with a molecular weight of $120 \mathrm{kDa}$, whereas the active form appears to be $\mathrm{L}_{2} \mathrm{H}$ with an apparent molecular weight of $69 \mathrm{kDa}$ [30]. In contrast, human tyrosinase is a monomeric membrane-bound glycoprotein with a molecular weight of $66.7 \mathrm{kDa}$ [29]. Song et al. suggested that there is no significant correlation between the inhibition of mushroom tyrosinase with human melanoma tyrosinase and melanogenesis [31]. A study on the inhibition of mushroom tyrosinase 
and the cellular tyrosinase activities of mulberroside A, oxyresveratrol, resveratrol, and arbutin also suggested that the in vitro inhibition rate of mushroom tyrosinase might not represent the inhibition rate of melanin synthesis for in vivo systems [9]. However, we suggest that, in flavonoids, anti-tyrosinase activity against mushroom would only appear in parallel with mammalian tyrosinase activity and melanogenesis inhibition when the enzyme inhibition activity in mushroom tyrosinase is greater than $60 \%$ at a concentration of $200 \mu \mathrm{M}$ or an $\mathrm{IC}_{50}$ lower than $50 \mu \mathrm{M}$. In other words, most flavonoids are likely to stimulate melanogenesis despite inhibiting mushroom tyrosinase activity.

\section{Materials and Methods}

\subsection{Chemicals}

3,4-Dihydroxy-L-phenylalanine (L-DOPA), kojic acid, oxyresveratrol, and mushroom tyrosinase were purchased from Sigma-Aldrich (St. Louis, MO, USA). The 27 flavonoids from D. parviflora were obtained from Kaoru Umehara [10,11].

\subsection{Mushroom Tyrosinase Inhibitory Assay}

The test samples, L-DOPA, and tyrosinase enzyme solutions were dissolved in 50\% $(v / v)$ dimethyl sulfoxide (DMSO) and $20 \mathrm{mM}$ phosphate buffer solution (PBS) of pH 6.8, respectively. The $o$-diphenolase activity of mushroom tyrosinase was performed in 96-well plates using a modified method of that performed by Likhitwitayawuid and Sritularak [32]. The reaction mixture consisted of $140 \mu \mathrm{L}$ of $20 \mathrm{mM}$ phosphate buffer at $\mathrm{pH} 6.8,20 \mu \mathrm{L}$ of test sample solution, and $20 \mu \mathrm{L}$ of mushroom tyrosinase (100 unit/mL, E.C. 1.14.18.1, Sigma). The mixture was pre-incubated at $25^{\circ} \mathrm{C}$ for $10 \mathrm{~min}$. Subsequently, $20 \mu \mathrm{L}$ of $2.5 \mathrm{mM} \mathrm{L-DOPA}$ was added, and the mixture was incubated for $20 \mathrm{~min}$ at $25^{\circ} \mathrm{C}$. During the reaction, L-DOPA was converted to dopachrome, which resulted in a change in color from colorless to orange. This change was measured through absorbance at $475 \mathrm{~nm}$. Instead of the sample solution, 50\% DMSO was used as the control. The reaction mixture without enzyme served as a blank. The inhibitory activity of the sample was expressed as the concentration that inhibits $50 \%$ of enzyme activity $\left(\mathrm{IC}_{50}\right)$.

\subsection{Cell Cultures}

Mus musculus (mouse) melanoma cell line, B16-F10 (ATCC ${ }^{\circledR}$ Number: CRL-6475 ${ }^{\mathrm{TM}}$, Manassas, VA, USA), was cultured in complete Dulbecco's Modified Eagle's Medium (DMEM, phenol red-free medium) containing 10\% fetal bovine serum, $25 \mathrm{mM}$ glucose, $4 \mathrm{mM}$ L-glutamine, $1 \mathrm{mM}$ sodium pyruvate, $10 \mu \mathrm{g} / \mathrm{mL}$ penicillin, and $10 \mu \mathrm{g} / \mathrm{mL}$ streptomycin, at $37^{\circ} \mathrm{C}$, with $5 \%$ carbon dioxide $\left(\mathrm{CO}_{2}\right)$ in a humidified atmosphere.

\subsection{Murine Tyrosinase Inhibitory Assay}

B16-F10 melanoma cells were grown to $100 \%$ confluence on $10 \mathrm{~cm}$ dishes. The trypsinized cells were washed with cold phosphate buffer $(20 \mathrm{mM}, \mathrm{pH} 6.8)$ and then disrupted in $1 \mathrm{~mL}$ of the buffer containing $1 \%$ Triton X-100. The cells were lysed by vortex and incubated at $4{ }^{\circ} \mathrm{C}$ for $1 \mathrm{~h}$ to solubilize the tyrosinase enzyme. The solution was centrifuged at $13,000 \times \mathrm{g}$ for $15 \mathrm{~min}$ at $4{ }^{\circ} \mathrm{C}$ to remove the cell debris. The supernatant was dialyzed against $20 \mathrm{mM}$ sodium phosphate buffer ( $\mathrm{pH} 6.8$ ) to remove the Triton X-100. The dialyzed solution was used as a source of crude murine tyrosinase enzyme. The solution contained $1 \mathrm{mg} / \mathrm{mL}$ protein, which was determined using a protein assay kit, based on the Bradford method (Bio-Rad Protein assay, Bio-Rad, Hercules, CA, US). The inhibitory activity was determined as described above for mushroom tyrosinase, but the incubation time was optimized at $2 \mathrm{~h}$ and $37^{\circ} \mathrm{C}$. 


\subsection{Cell Viability and Total Melanin Content Assay}

Cell viability and melanin content assay were performed in quadruplicate in at least three independent experiments. Cell viability was taken as the reducing power of the living cells that reduce resazurin-based solution (PrestoBlue ${ }^{\mathrm{TM}}$, Invitrogen, Carlsbad, CA, USA) to resorufin, which results in a bright red color and is highly fluorescent. Briefly, B16-F10 cells were cultured in a 96-well plate at a concentration of 10,000 cells $/ 0.1 \mathrm{~mL} /$ well. After incubating for $24 \mathrm{~h}$, equal volumes of fresh medium containing various concentrations of the test samples were added to the cells and were incubated for $72 \mathrm{~h}$. Cells were then washed with phosphate buffer, and then $0.1 \mathrm{~mL}$ of PrestoBlue ${ }^{\mathrm{TM}}$ solution in RMPI 1640 serum free media (1:10) was added to each well. After an hour, the fluorescence was quantified using spectrofluorophotometry (excitation $535 \mathrm{~nm}$, emission $610 \mathrm{~nm}$ ).

The total melanin content, produced both extracellularly and intracellularly, was determined as follows: B16-F10 cells were seeded onto a 24-well plate at a concentration of 50,000 cells $/ 0.5 \mathrm{~mL} /$ well and were incubated for $24 \mathrm{~h}$, followed by treatment with either the test compounds or the control (0.5\% DMSO), and then incubated for $72 \mathrm{~h}$. For extraction, the total produced melanin and $0.5 \mathrm{~mL}$ of $2 \mathrm{~N} \mathrm{NaOH}$ containing 20\% DMSO were added directly to the cell culture medium, mixed by pipetting and then incubated at room temperature for $1 \mathrm{~h}$. The lysed cell extract was centrifuged at $13,000 \times g$ for $5 \mathrm{~min}$. Finally, the supernatant was transferred to a 96 -well plate and the relative melanin content was detected at $405 \mathrm{~nm}$ using a micro plate reader. Kojic acid and oxyresveratrol were used as positive controls.

\section{Conclusions}

In conclusion, the results from the current study suggest that the enzyme-based assay using murine tyrosinase from B16-F10 melanoma cells is more appropriate than the mushroom tyrosinase for screening of natural compounds with potential whitening effects. The B16-F10 cells are also good for a cell-based assay for evaluating the direct effect of test compounds on melanin synthesis. Among all flavonoids from Dalbergia parviflora used in this test, $(6 \mathrm{a} R, 11 \mathrm{a} R)-3,8$-dihydroxy-9-methoxy pterocarpan (27) and cajanin (9) showed clear inhibitory activities on both methods. However, some flavonoids, particularly duartin (22), showed induction of cellular melanin synthesis without significant effect on the enzyme activity. The mechanism involved in the observed action is still not clear.

Author Contributions: Conceptualization, Worrawat Promden and Wanchai De-Eknamkul; Data curation, Worrawat Promden; Formal analysis, Worrawat Promden and Wittawat Viriyabancha; Investigation, Worrawat Promden; Methodology, Worrawat Promden; Resources, Orawan Monthakantirat, Kaoru Umehara, Hiroshi Noguchi and Wanchai De-Eknamkul; Supervision, Wanchai De-Eknamkul; Validation, Worrawat Promden; Visualization, Worrawat Promden; Writing_original draft, Worrawat Promden; Writing—review \& editing, Worrawat Promden and Wanchai De-Eknamkul.

Acknowledgments: We would like to acknowledge the financial support from the Center of Excellence on Medical Biotechnology (CEMB), S\&T Postgraduate Education and Research Development Office (PERDO), and the Higher Education Research Promotion (HERP) Program of the Office of Higher Education Commission (OHEC), Thailand.

Conflicts of Interest: The authors declare no conflict of interest.

\section{References}

1. Martinez, M.V.; Whitaker, J.R. The biochemistry and control of enzymatic browning. Trends Food Sci. Technol. 1995, 6, 195-200. [CrossRef]

2. Pillaiyar, T.; Manickam, M.; Namasivayam, V. Skin whitening agents: Medicinal chemistry perspective of tyrosinase inhibitors. J. Enzym. Inhib. Med. Chem. 2017, 32, 403-425. [CrossRef] [PubMed]

3. Chang, T.S. An updated review of tyrosinase inhibitors. Int. J. Mol. Sci. 2009, 10, 2440-2475. [CrossRef] [PubMed]

4. Parvez, S.; Kang, M.; Chung, H.S.; Bae, H. Naturally occurring tyrosinase inhibitors: Mechanism and applications in skin health, cosmetics and agriculture industries. Phytother. Res. 2007, 21, 805-816. [CrossRef] [PubMed] 
5. Seo, S.Y.; Sharma, V.K.; Sharma, N. Mushroom tyrosinase: Recent prospects. J. Agric. Food Chem. 2003, 51, 2837-2853. [CrossRef] [PubMed]

6. Kim, D.; Park, J.; Kim, J.; Han, C.; Yoon, J.; Kim, N.; Seo, J.; Lee, C. Flavonoids as mushroom tyrosinase inhibitors: A fluorescence quenching study. J. Agric. Food Chem. 2006, 54, 935-941. [CrossRef] [PubMed]

7. Kubo, I.; Kinst-Hori, I. Flavonols from saffron flower: Tyrosinase inhibitory activity and inhibition mechanism. J. Agric. Food Chem. 1999, 47, 4121-4125. [CrossRef] [PubMed]

8. Itoh, K.; Hirata, N.; Masuda, M.; Naruto, S.; Murata, K.; Wakabayashi, K.; Matsuda, H. Inhibitory effects of Citrus hassaku extract and its flavanone glycosides on melanogenesis. Biol. Pharm. Bull. 2009, 32, 410-415. [CrossRef] [PubMed]

9. Kim, J.H.; Park, K.T.; Lee, H.S.; Kim, M.; Lim, Y.H. Evaluation of the inhibition of mushroom tyrosinase and cellular tyrosinase activities of oxyresveratrol: Comparison with mulberroside A. J. Enzym. Inhib. Med. Chem. 2012, 27, 495-503. [CrossRef] [PubMed]

10. Umehara, K.; Nemoto, K.; Matsushita, A.; Terada, E.; Monthakantirat, O.; De-Eknamkul, W.; Miyase, T.; Warashina, T.; Degawa, M.; Noguchi, H. Flavonoids from the heartwood of the Thai medicinal plant Dalbergia parviflora and their effects on estrogenic-responsive human breast cancer cells. J. Nat. Prod. 2009, 72, 2163-2168. [CrossRef] [PubMed]

11. Umehara, K.; Nemoto, K.; Kimijima, K.; Matsushita, A.; Terada, E.; Monthakantirat, O.; De-Eknamkul, W.; Miyase, T.; Warashina, T.; Degawa, M.; et al. Estrogenic constituents of the heartwood of Dalbergia parviflora. Phytochemistry 2008, 69, 546-552. [CrossRef] [PubMed]

12. Promden, W.; Monthakantirat, O.; Umehara, K.; Noguchi, H.; De-Eknamkul, W. Structure and antioxidant activity relationships of isoflavonoids from Dalbergia parviflora. Molecules 2014, 19, 2226-2237. [CrossRef] [PubMed]

13. Kim, J.H.; Kim, M.R.; Lee, E.S.; Lee, C.H. Inhibitory effects of calycosin isolated from the root of Astragalus membranaceus on melanin biosynthesis. Biol. Pharm. Bull. 2009, 32, 264-268. [CrossRef] [PubMed]

14. Xie, L.P.; Chen, Q.X.; Huang, H.; Wang, H.Z.; Zhang, R.Q. Inhibitory effects of some flavonoids on the activity of mushroom tyrosinase. Biochemistry 2003, 68, 487-491. [PubMed]

15. Chang, T.S.; Ding, H.Y.; Lin, H.C. Identifying 6,7,4'-trihydroxyisoflavone as a potent tyrosinase inhibitor. Biosci. Biotechnol. Biochem. 2005, 69, 1999-2001. [CrossRef] [PubMed]

16. Chang, T.S. Two potent suicide substrates of mushroom tyrosinase: 7,8,4'-trihydroxyisoflavone and 5,7,8,4'-tetrahydroxyisoflavone. J. Agric. Food Chem. 2007, 55, 2010-2015. [CrossRef] [PubMed]

17. Satooka, H.; Kubo, I. Resveratrol as a $k_{\text {cat }}$ type inhibitor for tyrosinase: Potentiated melanogenesis inhibitor. Bioorganic Med. Chem. 2012, 20, 1090-1099. [CrossRef] [PubMed]

18. Bernard, P.; Berthon, J.Y. Resveratrol: An original mechanism on tyrosinase inhibition. Int. J. Cosmet. Sci. 2000, 22, 219-226. [CrossRef] [PubMed]

19. Gasowska-Bajger, B.; Wojtasek, H. Reactions of flavonoids with o-quinones interfere with the spectrophotometric assay of tyrosinase activity. J. Agric. Food Chem. 2016, 64, 5417-5427. [CrossRef] [PubMed]

20. Ozeki, H.; Ito, S.; Wakamatsu, K.; Thody, A.J. Spectrophotometric characterization of eumelanin and pheomelanin in hair. Pigment Cell Res. 1996, 9, 265-270. [CrossRef] [PubMed]

21. Kubo, I.; Nitoda, T.; Nihei, K. Effects of quercetin on mushroom tyrosinase and B16-F10 melanoma cells. Molecules 2007, 12, 1045-1056. [CrossRef] [PubMed]

22. Nagata, H.; Takekoshi, S.; Takeyama, R.; Homma, T.; Osamura, R.Y. Quercetin enhances melanogenesis by increasing the activity and synthesis of tyrosinase in human melanoma cells and in normal human melanocytes. Pigment Cell Res. 2004, 17, 66-73. [CrossRef] [PubMed]

23. Ohguchi, K.; Akao, Y.; Nozawa, Y. Stimulation of melanogenesis by the citrus flavonoid naringenin in mouse B16 melanoma cells. Biosci. Biotechnol. Biochem. 2006, 70, 1499-1501. [CrossRef] [PubMed]

24. Bouzaiene, N.N.; Chaabane, F.; Sassi, A.; Chekir-Ghedira, L.; Ghedira, K. Effect of apigenin-7-glucoside, genkwanin and naringenin on tyrosinase activity and melanin synthesis in B16F10 melanoma cells. Life Sci. 2016, 144, 80-85. [CrossRef] [PubMed]

25. Takekoshi, S.; Nagata, H.; Kitatani, K. Flavonoids enhance melanogenesis in human melanoma cells. Tokai J. Exp. Clin. Med. 2014, 39, 116-121. [PubMed]

26. Mayer, A.M. Polyphenol oxidases in plants and fungi: Going places? A review. Phytochemistry 2006, 67, 2318-2331. [CrossRef] [PubMed] 
27. Jaenicke, E.; Decker, H. Tyrosinases from crustaceans form hexamers. Biochem. J. 2003, 371, 515-523. [CrossRef] [PubMed]

28. Lerch, K. Neurospora tyrosinase: Structural, spectroscopic and catalytic properties. Mol. Cell. Biochem. 1983, 52, 125-138. [CrossRef] [PubMed]

29. Nishioka, K. Particulate tyrosinase of human malignant melanoma. Solubilization, purification following trypsin treatment, and characterization. Eur. J. Biochem. 1978, 85, 137-146. [CrossRef] [PubMed]

30. Strothkamp, K.G.; Jolley, R.L.; Mason, H.S. Quaternary structure of mushroom tyrosinase. Biochem. Biophys. Res. Commun. 1976, 70, 519-524. [CrossRef]

31. Song, T.Y.; Chen, C.H.; Yang, N.C.; Fu, C.S.; Chang, Y.T.; Chen, C.L. The correlation of in vitro mushroom tyrosinase activity with cellular tyrosinase activity and melanin formation in melanoma cells A2058. J. Food Drug Anal. 2009, 17, 156-162.

32. Likhitwitayawuid, K.; Sritularak, B. A new domeric stilbene with tyrosinase inhibitory activity from Artocarpus gomezianus. J. Nat. Prod. 2001, 64, 1457-1459. [CrossRef] [PubMed]

Sample Availability: All samples are available from the authors. 